\title{
INNOVATIVE DEVELOPMENT OF COUNTRIES: METHODOLOGY
}

\author{
Klimuk Vladimir \\ Candidate of Economic Sciences, Associate of Professor \\ Vice-rector on Scientific Work \\ Baranovichi State University \\ 21, Voikov str., Baranovichi, Brest region, Belarus, 225404 \\ e-mail: klimuk-vv@yandex.ru; ORCID: http://orcid.org/0000-0003-0928-8453 \\ Kochurko Vasilij \\ Doctor of Agricultural Sciences, Professor, Rector \\ Baranovichi State University \\ 21, Voikov str., Baranovichi, Brest region, Belarus, 225404 \\ e-mail: BarSU@brest.by
}

\begin{abstract}
This article analyzes the efficiency of innovative activity across countries and industries. Innovation determines the vector of development of the subject. They form a complex of practical inquiries, define scarce aspects in the functioning of organizations. However, the generation of new ideas is based on a detailed, clear system of actions: the study and analysis of the situation on the market, the demands of society, the formation of an algorithm for creating innovative solutions, schemes for their implementation in the practice of organizations. In the article, the authors proposed a methodology for assessing the level of innovative development of the country. The methodology is based on the use of quantitative indicators in three areas: the effectiveness of the use of labor resources; efficiency of the use of financial resources; efficiency of the use of invested funds.

The authors offers his interpretation of the concept «model of innovation development». Tools for the quantitative assessment of level of innovative development of countries and formation of the vector of economic development based on indicators grouped under the following three components were developed: labor, productivity and cost. This study also investigates the structure of domestic expenditure on innovation in the main sectors of investment (by country). Based on the testing of the developed tools, recommendations for the innovative development of the country are offered.

A set of quantitative indicators will allow performing a qualitative analysis of the dynamics of the country's development in the innovation vector of functioning, identifying weaknesses (existing shortcomings) in activities. This will allow to form a set of effective recommendations on the activation of innovative activities in the country with the aim of raising the level of competition.
\end{abstract}

Key words: economic innovation, tools, development trend, innovative level, factors, recommendations.

The modern era of rapid development of information technologies, automated systems, creative methods, and new types of products, sets tough conditions for ensuring market competitiveness. These conditions, which include originality, economy, standards, environmental friendliness, mobility and a number of others, dictate the urgent need for rapid adaptation to market metamorphoses, manifested in the activation of innovative activity on the principle of «being in the lead» (with an emphasis on the indicator of the quality of the result, and not a quantitative basis). Thus, innovations are the dominant source of socio-economic growth of a country, creating a platform that forces technical and technological excellence, economic and environmental benefits, and social security.

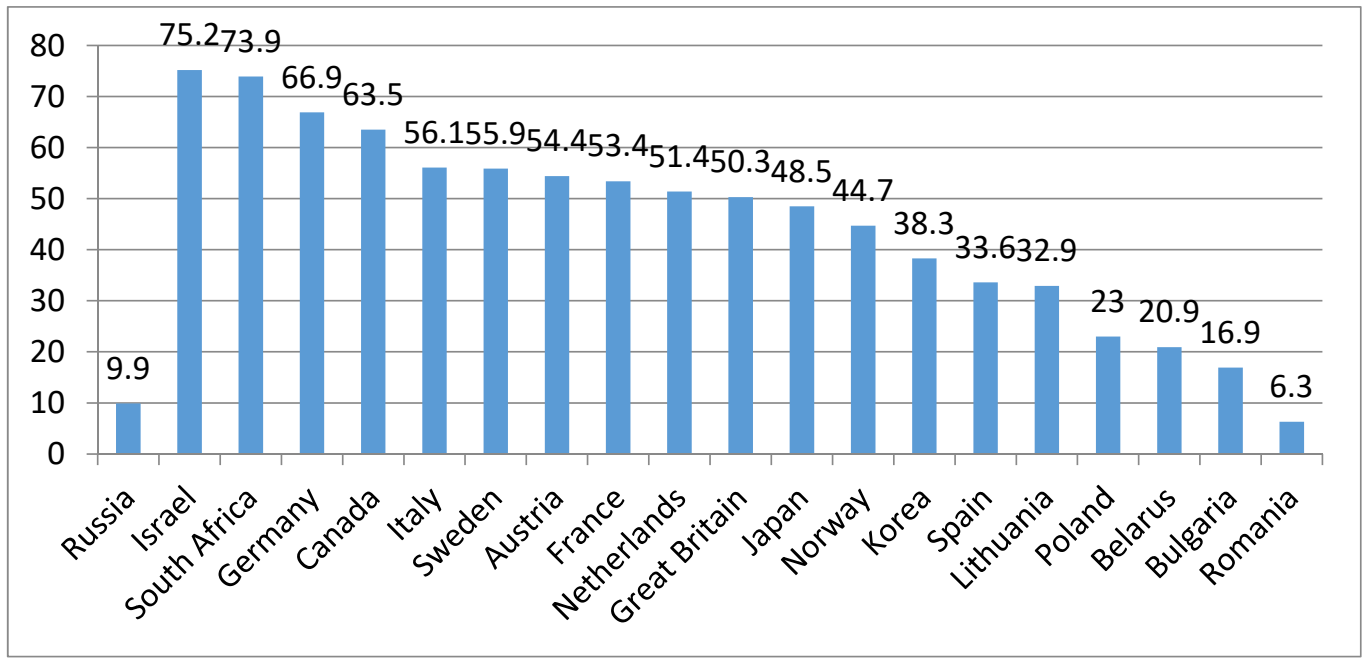

Figure 1 - Aggregate level of innovation activity by countries, \%

Notation - Collection «Indicators of innovation activity - 2016». 
On the one hand, a country's total aspiration for innovation determines the potential for improving the quality of life, the diversification of economic activity, and ensures the barrier-free functioning of the state. However, on the other hand, there may be an increase in incidents of unfair competition, which can result in a significant "overflow" of capital from "underdeveloped" countries to the innovative development of "developed" countries, which will ensure an already huge economic development gap between individual countries (Figure 1).In Russia, the largest share of innovation organizations logically lies within the high-tech sector of manufacturing $(32 \%$ of the total number of organizations in the country), and the smallest - within the sector of the production and distribution of electricity, gas and water (5.1\%) (Figure 2).

In Belarus, a high share of the innovative development of the country is concentrated on the acquisition of machinery and equipment (53\%), which can be characterized by the consumption function (the consumption of existing innovations, rather than their independent creation) (Figure 3).

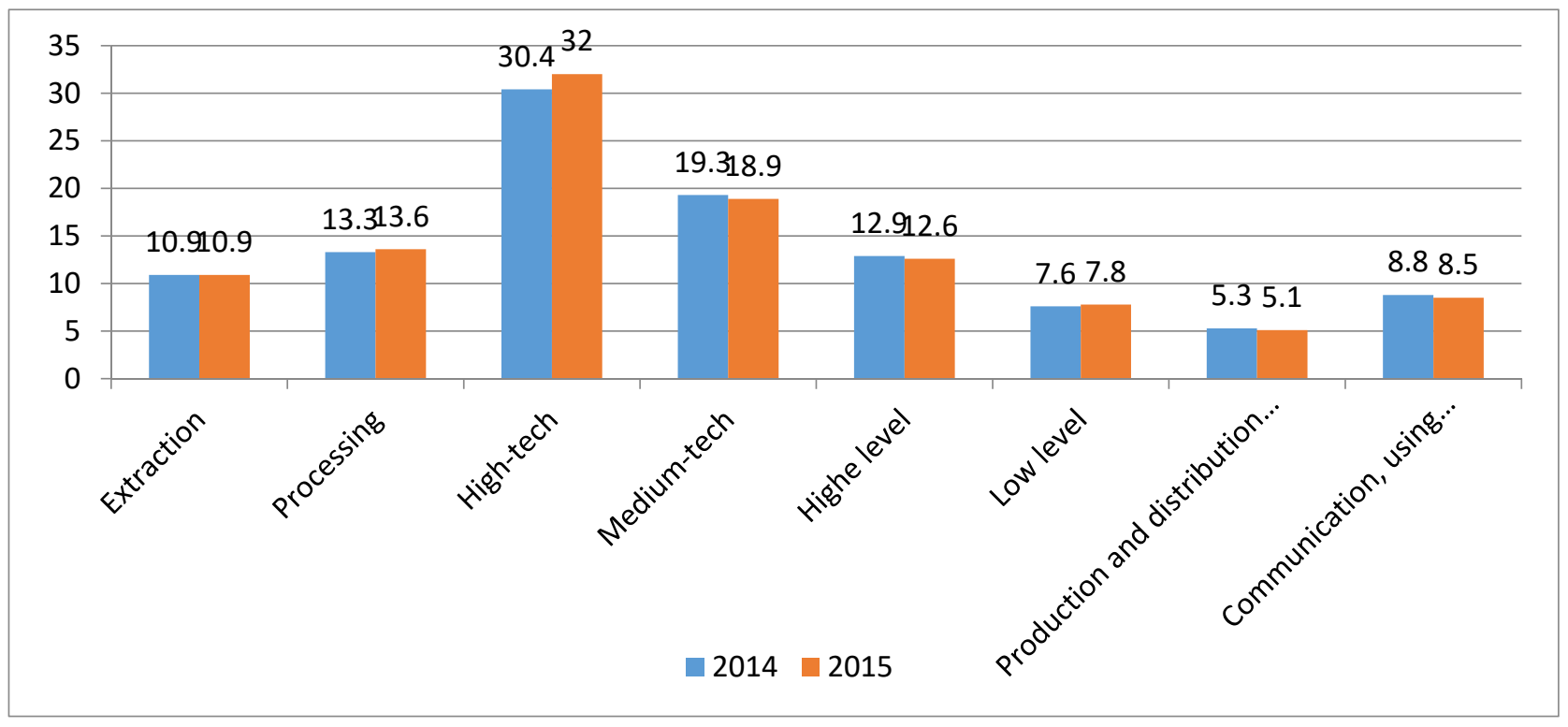

Figure 2. - Aggregate innovation activity by industry, \%

Notation - Collection «Indicators of innovation activity - 2016».

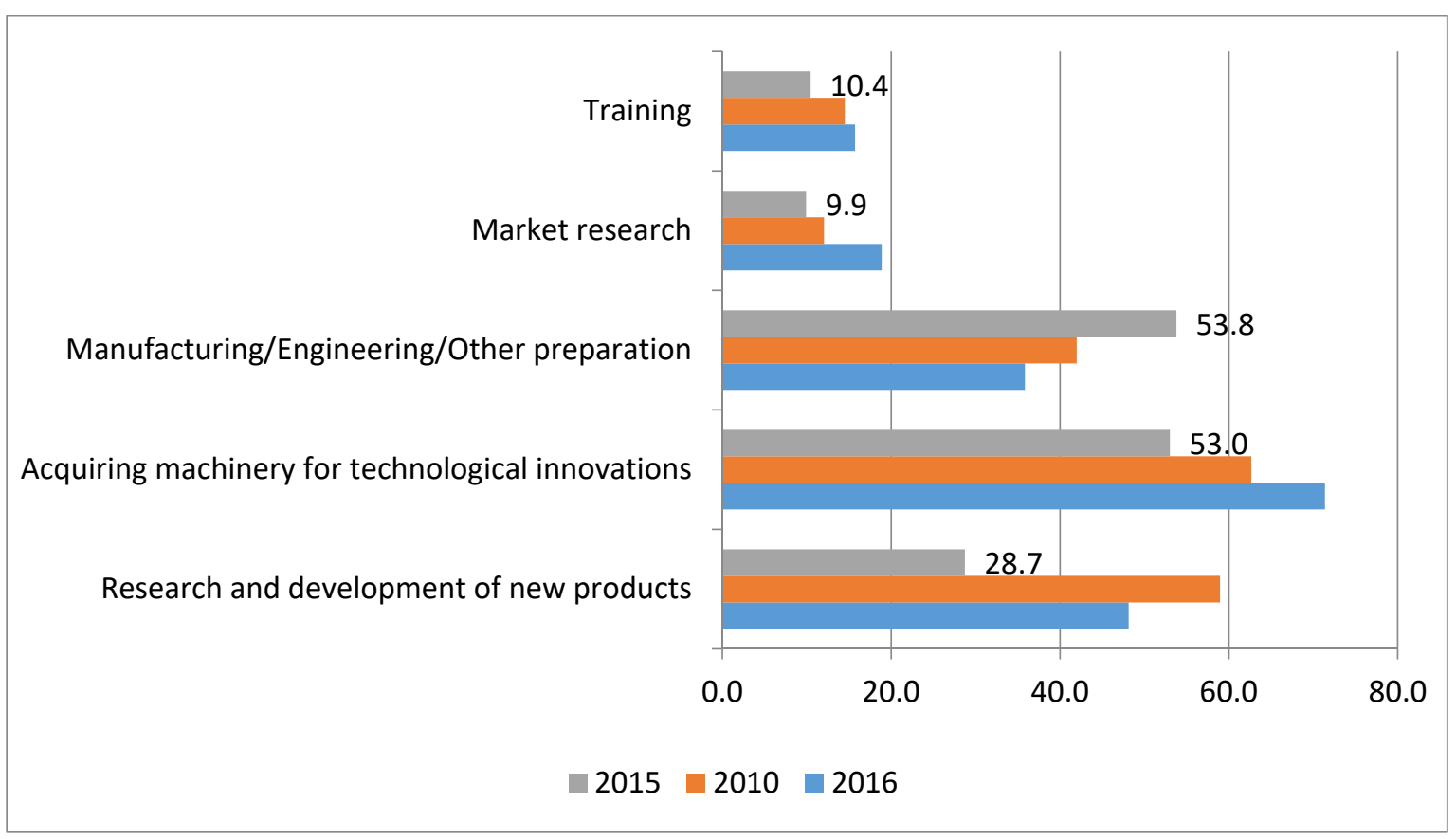

Figure 3. - Structure of the specialization of innovation organizations as the total number of innovative activities in Belarus, \%

Notation - Source: compiled by the author on the basis of [Statistical Digest "Science and Innovation in Belarus. 2015]. 
Looking at the role of innovative products and technologies of any era, it is crucial to observe a country's state of development. Moreover, the comparison of the current level of development and potential opportunities, as well as the model of innovative development of the current and projected, serve as the underlying motive of this work.

Modeling issues of innovative development is given the lion's share of research, which is associated with the economic effect of using their results in practice.

The modeling of an organization's innovative development is given special attention in the works of Averina T.A. [1], which summarize the following types of models: the model of technological change; the model of a destructive event; the model of generations of innovative development; the model of the dependence of the economic efficiency of implementing innovations in the real sector of the economy from the trajectory of innovative development by product. In the works of Milevskaya T.S. [8] three models of innovative development of countries are distinguished: Traditional, European, Asian; all based on the life cycle of the innovation process and management structure.

The prioritization of development, the existing potential for excellence, and incentive mechanisms, explain the differentiation of the levels of innovative development of countries and possible trends in their deformation. We created a model that includes a set of tools and methods a country can use to move in a trajectory of innovation. We have proposed the following interpretation of this kind of model: «A model of innovation development is an integral vector of development based on the improvement of organizational, managerial, technical-technological, and economic processes of functioning, forming a platform of competitiveness and socio-ecological and economic security of the country» $[2,14]$.

Based on the methods that are used to stimulate the innovative activity of the existing technical, raw material and intellectual base of the planned positions on a global scale of economic prosperity, different types of models are singled out. The study of the works on this subject made it possible to generalize existing models on two grounds: territorial features and a set of mechanisms for the implementation of the innovation vector. In order to quantify the level of innovative development of countries and form the "vector of the future», the following system of relative indicators (with the aim of unifying the applicable indicators and the possibility of intercountry comparison) is proposed $[3,12]$. The indicators are grouped according to the leading components $[7,9]$ :

- The labor component:

- 1-Budget for minimum wage/wage

- $\quad$ Proportion of population with a higher education

- $\quad$ Proportion of those who have those who have presented their work in order to get a PhD
- The proportion of researchers with a degree within the total number of researchers.

- Efficiency component:

- Proportion of active innovative organizations.

- $\quad$ Proportion of innovative products within total production.

- $\quad$ Proportion of exports of innovative products within the total volume of shipped products.

- $\quad$ Proportion of patents granted within the total number of applications filed.

- Proportion of global innovations within the country's total volume of innovative products.

- The cost component:

- Proportion of costs for innovation within the total volume of innovative products.

- $\quad$ Proportion of expenses for innovation activity within the total volume of investments in the country (region).

- $\quad$ Proportion of worn-out machinery and equipment.

This set of indicators will provide an opportunity to assess the level of innovation development for the current or retrospective period, and also act as a platform for the country's development strategy to improve its level of innovation $[4,6,13,15]$.

One of the most important factors and conditions for the activation of innovative activity are investment funds that ensure the implementation of multi-vector functions, the development of certain tasks, as well as the approbation and implementation of innovations in practice (Figure 4).

The largest share in the structure of domestic costs within a country is entrepreneurship (except for Latvia, since their priority is high school), which is the lever of economic dynamics and innovative metamorphoses at the micro level $[5,10]$. It ensures the wide-spread application of new products that have already passed the initial stage of testing.

Intellectual resources are the main factor of innovative development, the structure of which varies considerably by country (Figure 5).

Mechanisms for stimulating the country's innovative development, tools for assessing its level, and prospective development trajectories all form models of innovative development, the differentiation of which can be represented in the following structure:

1. Productive (each type of innovation provides high indications).

2. Cloning (specialize in the development and creation of one type of innovation, not all).

3. Catching up (by their own efforts, but at a slower pace, they create their own innovations).

To assess the level of innovative development, the proposed method was used to calculate and analyze, according to the algorithm described above, for the comparison of Republic of Belarus and the Russian Federation (Table 1) 


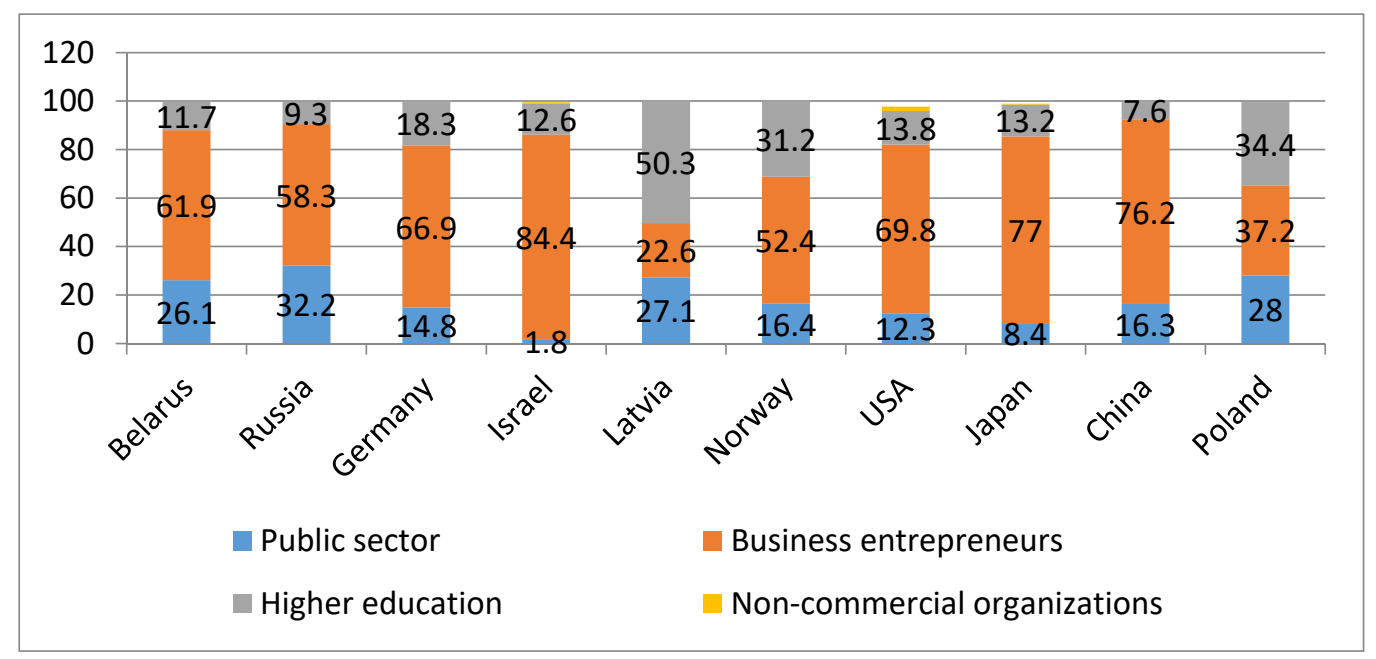

Figure 4 - Structure of domestic costs for innovation in each country in 2015, \%

Notation 1. Compiled by the author on the basis of [Statistical Digest «Science and Innovation in Belarus. 2015»].

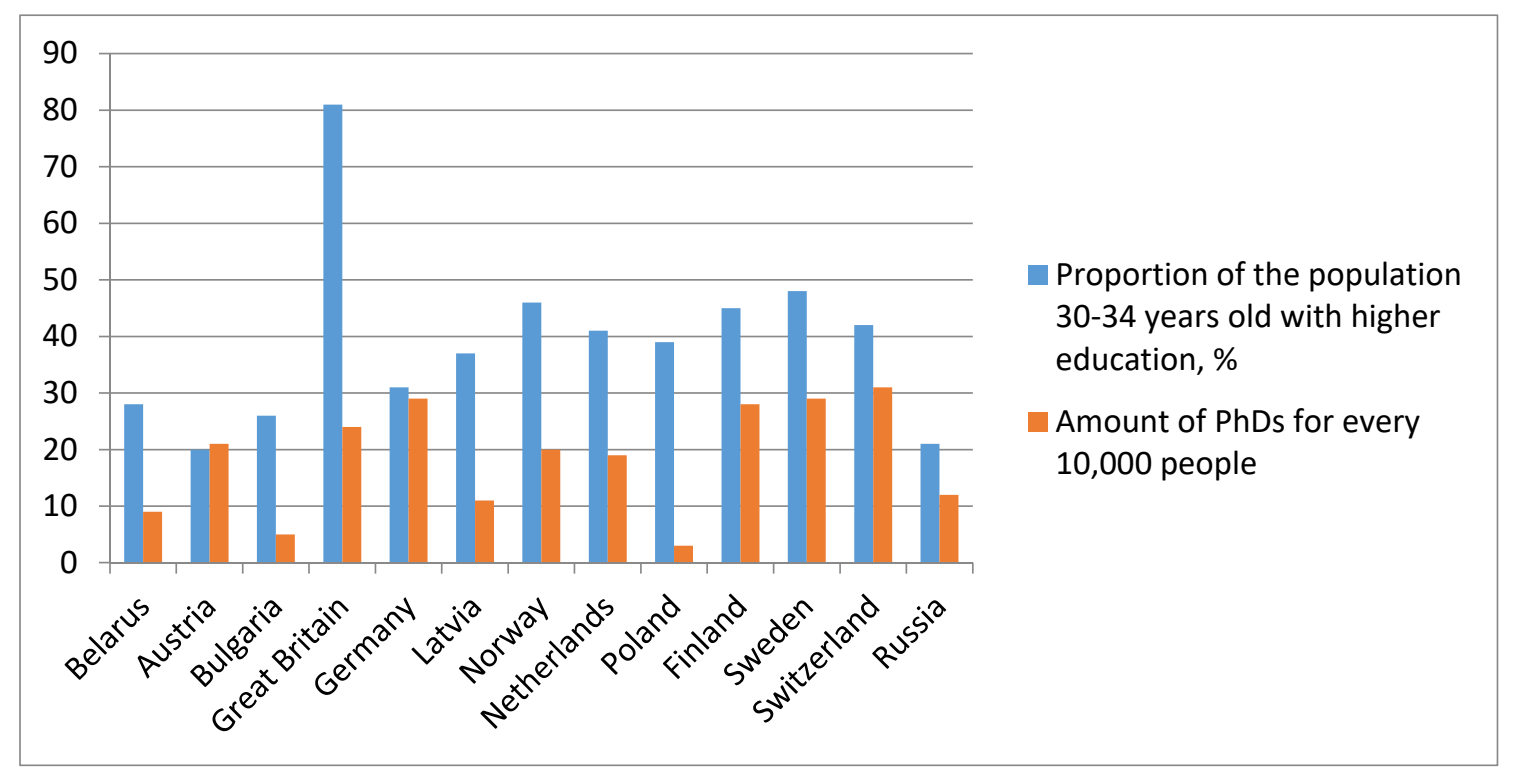

Figure 5 - Structure of innovation activity of labor resources in each country in 2015, \%

Notation 1. Compiled by the author on the basis of [Statistical Digest «Science and Innovation in Belarus. 2015»]

Table 1

Results of the assessment of innovative development of the Republic of Belarus and the Russian Federation between years 2006 and 2015.

\begin{tabular}{|c|c|c|c|c|c|c|}
\hline Indicators & Year 2006 & Year 2011 & Year 2012 & Year 2013 & Year 2014 & Year 2015 \\
\hline \multicolumn{7}{|c|}{ Republic of Belarus } \\
\hline 1. Labor component & 0,2025 & 0,1704 & 0,1774 & 0,1936 & 0,1928 & 0,2112 \\
\hline $\begin{array}{l}1 \text { - Budget for minimum } \\
\text { wage/wage }\end{array}$ & 0,7727 & 0,8451 & 0,8212 & 0,8318 & 0,8496 & 0,8355 \\
\hline $\begin{array}{l}\text { Proportion of population } \\
\text { with a higher education }\end{array}$ & 0,2020 & 0,2080 & 0,2100 & 0,2170 & 0,2250 & 0,2340 \\
\hline $\begin{array}{l}\text { Proportion of those who } \\
\text { want to get a PhD }\end{array}$ & 0,0491 & 0,0245 & 0,0290 & 0,0397 & 0,0363 & 0,0499 \\
\hline Proportionofresearchers & 0,2196 & 0,1956 & 0,1978 & 0,1962 & 0,1988 & 0,2037 \\
\hline
\end{tabular}


International relations. Economics. Country Studies. Tourism (IRECST)

\begin{tabular}{|c|c|c|c|c|c|c|}
\hline Indicators & Year 2006 & Year 2011 & Year 2012 & Year 2013 & Year 2014 & Year 2015 \\
\hline 2. Efficiency component & 0,1081 & 0,0987 & 0,1282 & 0,1287 & 0,1272 & 0,1079 \\
\hline $\begin{array}{l}\text { Proportion of active inno- } \\
\text { vative organizations }\end{array}$ & 0,1410 & 0,1540 & 0,2270 & 0,2280 & 0,2170 & 0,2090 \\
\hline $\begin{array}{l}\text { Proportion of innovative } \\
\text { products within total pro- } \\
\text { duction }\end{array}$ & 0,1520 & 0,1450 & 0,1440 & 0,1780 & 0,1780 & 0,1390 \\
\hline $\begin{array}{l}\text { Proportion of exports of } \\
\text { innovative products } \\
\text { within the total volume of } \\
\text { shipped products }\end{array}$ & 0,1209 & 0,0736 & 0,0897 & 0,1148 & 0,1096 & 0,0830 \\
\hline $\begin{array}{l}\text { Proportion of patents } \\
\text { granted within the total } \\
\text { number of applications } \\
\text { filed }\end{array}$ & 0,7127 & 0,6322 & 0,7878 & 0,6900 & 0,6836 & 0,5048 \\
\hline $\begin{array}{l}\text { Proportion of global inno- } \\
\text { vations within the coun- } \\
\text { try's total volume of inno- } \\
\text { vative products }\end{array}$ & 0,0080 & 0,0090 & 0,0150 & 0,0110 & 0,0115 & 0,0120 \\
\hline 3. Cost Component & 0,4530 & 0,5199 & 0,5428 & 0,5564 & 0,5429 & 0,5340 \\
\hline $\begin{array}{l}\text { 1- Proportion of costs for } \\
\text { innovations within the to- } \\
\text { tal number of innovative } \\
\text { products }\end{array}$ & 0,7713 & 0,8200 & 0,8260 & 0,8453 & 0,8460 & 0,8533 \\
\hline $\begin{array}{l}\text { Proportion of investments } \\
\text { on reconstruction and } \\
\text { modernization }\end{array}$ & 0,2510 & 0,2960 & 0,3190 & 0,3330 & 0,3080 & 0,2850 \\
\hline $\begin{array}{l}\text { 1- Proportion of worn-out } \\
\text { machinery and equip- } \\
\text { ment }\end{array}$ & 0,4800 & 0,5790 & 0,6070 & 0,6120 & 0,6140 & 0,6260 \\
\hline Integral Estimate & 0,2149 & 0,2060 & 0,2311 & 0,2403 & 0,2370 & 0,2300 \\
\hline \multicolumn{7}{|c|}{ Russian Federation } \\
\hline 1. Labor component & 0,2797 & 0,2728 & 0,2863 & 0,2946 & 0,2991 & 0,3066 \\
\hline $\begin{array}{l}\text { 1- Budget for minimum } \\
\text { wage/wage }\end{array}$ & 0,5272 & 0,4557 & 0,5709 & 0,6037 & 0,6212 & 0,6646 \\
\hline $\begin{array}{l}\text { Proportion of population } \\
\text { with a higher education }\end{array}$ & 0,2080 & 0,2020 & 0,2110 & 0,2120 & 0,2150 & 0,2180 \\
\hline $\begin{array}{l}\text { Proportion of those who } \\
\text { want to get a PhD }\end{array}$ & 0,2270 & 0,2360 & 0,2120 & 0,2180 & 0,2210 & 0,2250 \\
\hline Proportionofresearchers & 0,2460 & 0,2550 & 0,2630 & 0,2700 & 0,2710 & 0,2710 \\
\hline 2. Efficiency component & 0,1369 & 0,1284 & 0,1485 & 0,1513 & 0,1562 & 0,1531 \\
\hline $\begin{array}{l}\text { Proportion of active inno- } \\
\text { vative organizations }\end{array}$ & 0,1020 & 0,1080 & 0,1110 & 0,1110 & 0,1090 & 0,1090 \\
\hline $\begin{array}{l}\text { Proportion of innovative } \\
\text { products within total pro- } \\
\text { duction }\end{array}$ & 0,0900 & 0,0480 & 0,0545 & 0,0540 & 0,0640 & 0,0575 \\
\hline $\begin{array}{l}\text { Proportion of exports of } \\
\text { innovative products } \\
\text { within the total volume of } \\
\text { shipped products }\end{array}$ & 0,2570 & 0,1861 & 0,3076 & 0,3202 & 0,3146 & 0,3077 \\
\hline
\end{tabular}


Вісник ХНУ імені В.Н. Каразіна. Серія “Міжнародні відносини. Економіка. Країнознавство. Туризм”. Вип. 8, 2018

\begin{tabular}{|c|c|c|c|c|c|c|}
\hline Indicators & Year 2006 & Year 2011 & Year 2012 & Year 2013 & Year 2014 & Year 2015 \\
\hline $\begin{array}{l}\text { Proportion of patents } \\
\text { granted within the total } \\
\text { number of applications } \\
\text { filed }\end{array}$ & 0,6800 & 0,6820 & 0,6700 & 0,6890 & 0,6950 & 0,7040 \\
\hline $\begin{array}{l}\text { Proportion of global inno- } \\
\text { vations within the coun- } \\
\text { try's total volume of inno- } \\
\text { vative products }\end{array}$ & 0,0300 & 0,0530 & 0,0580 & 0,0600 & 0,0610 & 0,0620 \\
\hline 3. Cost Component & 0,4290 & 0,3968 & 0,4079 & 0,4289 & 0,4329 & 0,4345 \\
\hline $\begin{array}{l}\text { 1- Proportion of costs for } \\
\text { innovations within the to- } \\
\text { tal number of innovative } \\
\text { products }\end{array}$ & 0,7568 & 0,6838 & 0,6840 & 0,7401 & 0,7414 & 0,7388 \\
\hline $\begin{array}{l}\text { Proportion of investments } \\
\text { on reconstruction and } \\
\text { modernization }\end{array}$ & 0,2820 & 0,2610 & 0,2740 & 0,2890 & 0,2950 & 0,3000 \\
\hline $\begin{array}{l}\text { 1- Proportion of worn-out } \\
\text { machinery and equip- } \\
\text { ment }\end{array}$ & 0,3700 & 0,3500 & 0,3620 & 0,3690 & 0,3710 & 0,3700 \\
\hline Integral Estimate & 0,2542 & 0,2404 & 0,2589 & 0,2674 & 0,2725 & 0,2732 \\
\hline
\end{tabular}

Notation: Compiled by the author on the basis of [Statistical Digest «Science and Innovation in Belarus. 2015», «Indicatorsofinnovation: 2016». Statisticalcompilation. - Moscow: NIUHSE, 2016. - 320 p.].

As for recommendations on expanding opportunities and increasing the degree of innovative development of countries, we suggest the following:

1. Strengthening of measures of material stimulation for workers in the development of the economy's innovation sector (introduction of the differentiated system of progressive awarding, expansion of programs of financing of innovative projects).
2. Formation of alliance economic systems (based on vertical and horizontal integration schemes ensuring prompt delivery, quality of raw materials, real buyers).

3. Development of innovative infrastructure (expansion of the number of technology parks, innovation funds, venture firms, approbation of start-up projects).

\section{ІННОВАЦІЙНИЙ РОЗВИТОК КРАЇН: МЕТОДОЛОГІЯ}

Клімук Володимир Володимирович, кандидат економічних наук, доцент, проректор з наукової роботи, Установа освіти "Барановичський державний університет", вул. Войкова, 21, м Барановичі, Брестська область, Республіка Білорусь, 225404, e-mail: klimuk-vv@yandex.ru; ORCID: http://orcid.org/0000-0003-0928-8453

Кочурко Василій Іванович, доктор сільськогосподарських наук, професор, ректор, Установа освіти "Барановичський державний університет", вул. Войкова, 21, м. Барановичі, Брестська область, Республіка Білорусь, 225404, e-mail: BarSU@brest.by

У статті аналізується ефективність інноваційної діяльності у різних країнах та галузях. Інновація визначає вектор розвитку предмету. Разом вони утворюють комплекс практичних запитів, визначають дефріцитні аспекти функціонування організацій. Однак генерація нових ідей ґрунтується на детальній, чіткій системі дій: вивченні та аналізі ситуації на ринку, вимогах суспільства, фоормуванні алгоритму створення інноваційних рішень, схем їх реалізації в практиці організацій. У статті автори запропонували методику оцінки рівня інноваційного розвитку країни. Методологія базується на використанні кількісних показників у трьох напрямках: ефективності використання трудових ресурсів; ефективність використання фінансових ресурсів; ефективність використання інвестованих коштів.

Автори пропонують своє тлумачення поняття «модель інноваційного розвитку». Розроблено інструменти кількісної оцінки рівня інноваційного розвитку країн та формування вектору економічного розвитку на основі показників, згрупованих за наступними трьома компонентами: праця, продуктивність та вартість. Це дослідження також висвітлює структуру внутрішніх витрат на інновації в основних секторах інвестицій (по країнах). На основі тестування розроблених інструментів пропонуються рекомендації щодо інноваційного розвитку країни.

Сукупність кількісних показників дозволить провести якісний аналіз динаміки розвитку країни в інноваційному векторі функціонування, визначити недоліки (наявні недоліки) у діяльності. Це дозволить сформувати комплекс ефективних рекомендацій щодо активізації інноваційної діяльності в країні з метою підвищення рівня конкуренції.

Ключові слова: економічні інновації, інструменти, тенденція розвитку, інноваційний рівень, фактори, рекомендації. 


\section{ИННОВАЦИОННОЕ РАЗВИТИЕ СТРАН: МЕТОДОЛОГИЯ}

Климук Владимир Владимирович, кандидат экономических наук, доцент, проректор по научной работе, Учреждение образования "Барановичский государственный университет", ул. Войкова, 21, г. Барановичи, Брестская область, Республика Белаpycь, 225404, e-mail: klimuk-vv@yandex.ru; ORCID: http://orcid.org/0000-0003-0928-8453

Кочурко Василий Иванович, доктор сельскохозяйственных наук, профессор, ректор, Учреждение образования "Барановичский государственный университет", ул. Войкова, 21, г. Барановичи, Брестская область, Республика Беларусь, 225404, е-таі: BarSU@brest.by

В статье анализируется эффективность инновационной деятельности в различных странах и отраслях. Инновация определяет вектор развития предмета. Вместе они образуют комплекс практических запросов, определяют дефицитные аспекты функционирования организаций. Однако генерация новых идей основывается на детальной, четкой системе действий: изучении и анализе ситуации на рынке, требованиях общества, формировании алгоритма создания инновационных решений, схем их реализации в практике организаций. В статье авторы предложили методику оценки уровня инновационного развития страны. Методология базируется на использовании количественных показателей в трех направлениях: эффективности использования трудовых ресурсов; эффективность использования финансовых ресурсов; эффективность использования инвестированных средств.

Авторы предлагают свое толкование понятия «модель инновационного развития». Разработаны инструменты количественной оценки уровня инновационного развития стран и формирования вектора экономического развития на основе показателей, сгруппированных по следующим трем компонентам: труд, производительность и стоимость. Это исследование также освещает структуру внутренних затрат на инновации в основных секторах инвестиций (по странам). На основе тестирования разработанных инструментов предлагаются рекомендации по инновационному развитию страны.

Совокупность количественных показателей позволит провести качественный анализ динамики развития страны в инновационном векторе функционирования, определить недостатки (имеющиеся недостатки) в деятельности. Это позволит сформировать комплекс эффективных рекомендаций по активизации инновационной деятельности в стране с целью повышения уровня конкуренции.

Ключевые слова: экономические инновации, инструменты, тенденция развития, инновационный уровень, факторы, рекомендации.

\section{References}

1. Averina T.A. Analysis of models and methods of management of the innovative development of the enterprise / Scientific Herald of the Voronezh State Architectural and Construction University. Series: Management of construction. - 2014. - No. 1 (6). - P. 76-83.

2. Alisejko E., Babenko V., Kochuyeva, Z. The task of minimax adaptive management of innovative processes at an enterprise with risk assessment. Innovative technologies and scientific solutions for industries, 2017. - No. 1 (1). P. 6-13. DOI: https://doi.org/10.30837/2522-9818.2017.1.006

3. Babenko V. Modeling of factors influencing innovation activities of agricultural enterprises of Ukraine // Scientific Bulletin of Polissia. - 2017. - № 1 (9), p. 2. - P. 115-121. DOI: 10.25140/2410-9576-2017-2-2(10)

4. GoldyakovaT.V. Concept and classification of innovations / Russian foreign economic bulletin. - 2006. - №2. P. 20-27.

5. Indicators of innovation: 2016. Statistical compilation. - Moscow: NIU HSE, 2016. - 320 p.

6. Lvov D.S., GlazyevS.Yu. Theoretical and Applied Aspects of NTP Management // Economics and Mathematical Methods: Journal. - M., 1986. - № 5. - P. 793-804.

7. Matveeva, L.G., Chernova, OA, Klimuk, V.V. Evaluation of the effectiveness of import substitution policies in industry: methodological tools / L.G. Matveeva, O.A. Chernova, V.V. Klimuk // News of the Far Eastern Federal University. Economics and Management. - 2015. - No. 3 (75). Pp. 3-14.

8. Milevska T.S. Models of innovative development of economics / Business Inform. - 2012. - №7. - P. 40-46.

9. Postaljuk M.P., Gusarova V.U. Mechanisms for ensuring innovation in economic development structures / Problems of modernization and transition to an innovative economy. - 2014. - P. 27-30.

10. Praslov A.V. Classification of innovations and their essence / News from the Russian State Pedagogical University. A.I. Herzen. - 2007. - P. 156-162.

11. Sampieva L.D., Tamashev I.M. Principles and features of innovative development of enterprises of the agroindustrial complex / TERRA ECONOMICUS. - 2011. - T. 9. - № 4. - Part 3. - P. 145-147.

12. Babenko V., Nakisko O., Mykolenko I. Research of the aspects of modeling of the project management of risk of implementation system information support // Technology audit and production reserves. - Vol. 1, No 4(39), 2018. - P. 64-69. DOI: 10.15587/2312-8372.2018.124538

13. Sidorov V., Babenko V., Bondarenko M. Researching factors of innovative activities of agrarian business of Ukraine under globalization of the world economy. Innovative technologies and scientific solutions for industries, 2017. No. 2 (2). DOI: https://doi.org/10.30837/2522-9818.2017.2.070

14. Babenko V., Abdel-Badeeh M. Salem. Modeling of the Control of Innovative Processes of a Production Activity Taking into Account Risks / International journal of economics and statistics. - 2018. - Vol. 6, P. 99-104. URL: http://naun.org/cms.action? id $=18790$

15. Chernov O.A., Sadovnikov A.S. Mechanisms of activation of innovative activity of enterprises / Modern problems of science and education. - 2015. - No. 1-1. - P. 759-765. 